Discourse and Communication for Sustainable Education, vol. 10, no. 2, pp. 72-88, 2019

\title{
Teachers' Perceptions of Consumer Education in Primary Schools in Finland
}

\author{
Kati Pajari and Sari Harmoinen \\ University of Oulu, Oulu, Finland
}

\begin{abstract}
Operating in today's markets is challenging due to information overload and an expanding choice of products. Children also encounter these complex markets at an early age. Providing consumer education in schools is an excellent opportunity to enhance their ability to think critically and increase their awareness. However, it would be a mistake to ignore the interconnections between consumer education and entrepreneurship education, since active and innovative people are also a prerequisite for future development. Taking advantage of the opportunity to provide consumer education in schools requires teachers to be familiar with consumer issues. This article aims to discuss the perceptions and experiences that primary school teachers in Finland have regarding children's consumer education in schools. This study was conducted using the phenomenographic qualitative method to analyse data from teacher interviews. The analysis revealed a set of categories that describes the various ways the participants perceive and experience children's consumer education in schools. These categories include themes, actors, teaching methods and the challenges and expectations teachers relate to children's consumer education. The findings of this study are worth exploring when planning how to support teachers' consumer educational competences for a sustainable future. The authors consider that this article is especially valuable for curriculum planners, educators, consumer organisations and parents' associations, because it shed light on teachers' perspectives about consumer education.
\end{abstract}

Key words: education for sustainable development, consumer education, entrepreneurship education, financial literacy.

\section{Introduction}

It is Monday morning, and the school week has just begun. Some of the pupils are eager to talk about how they went shopping over the weekend with their families. Soon, the discussion turns to the subject of the lesson: sustainable consumption. The impact of one's consumption decisions on the environment is also discussed. Suddenly, the children might feel confused. Sustainable development and critical consumerism seem to be important, but why did it feel so nice to buy something shiny and new over the weekend? 
As shown in the example above, children's consumer education is a challenge for teachers. Consumerism is a very complex and ambivalent phenomenon, which does not make this challenge easier (Wilska, 2008, p. 43). However, in Europe, consumers have a legal right to receive consumer education, and the aim of the European Community and the Member States is to work together to meet that objective (Nordic Council of Ministers, 2010). This represents an important opportunity to provide children with consumer education in schools (OECD, 2009).

The Organisation for Economic Co-operation and Development (OECD) (2009, p. 3) has defined consumer education as "a process of developing and enhancing skills and knowledge to make informed and well-reasoned choices that take societal values and objectives into account". Operating in today's complex markets is challenged by information overload and an expanding choice of products (OECD, 2009). Children also encounter these complex markets at an early age. Research shows that children have a significant influence on families' purchasing decisions (Nordic Council of Ministers, 2010). According to McNeal (2007), in 2005 American children, ranging in age from 4 to 12 , spent $\$ 42$ billion of their own money on products and services, and children, ranging in age from 2 to 14, have a direct and indirect impact on their parents' spending, which amounts to more than $\$ 700$ billion. Thus, OECD (2009) has suggested that consumer education should cover all life stages, including childhood. Consequently, it is surprising that educational institutions are not specifically mentioned, for example, in the European Union (EU) strategies to raise awareness of the problems of plastic products and plastic waste (Kerscher, 2019). Kerscher (2019) noted that primary and secondary educational institutions must be involved in the effort to support sustainable changes regarding people's consumption patterns.

Roland-Lévy (2010) has found that the importance of budgeting, the benefits of saving and understanding the value of money become more concrete for children when they have direct experiences with money. She has suggested that both parents and teachers should try to take a more systematic approach to ensure that children have a better understanding of money. However, not all children have the same perceptions and attitudes towards money at one specific time across the globe (Roland-Lévy, 2010). The opportunity to spend money also varies. Therefore, it is crucial that a teacher knows his/ her pupils and what is relevant in their daily lives. Understanding the conceptual contradictions and recognising their interconnections in children's lives requires teachers to have a good knowledge of the subject and to understand the experiences of their pupils (Rajala et al., 2015). Financial literacy has a significant impact on both an individual's personal life and on society. As financial literacy develops, it strengthens the ability to make informed decisions, enhances household planning and management skills and enables one to demand higher quality services, thereby encouraging competition and innovation (Goldsmith \& Piscopo, 2014). Consumer education enhances critical thinking and increases awareness, thereby enabling consumers to become more pro-active (OECD, 2009).

It is important to address the interconnections between consumer education and entrepreneurship education. While entrepreneurship education is a relatively new research field (Low, 2001; Fayolle, 2008), the same old questions emerge; for example, many practitioners and educators still believe that entrepreneurship education should only be concerned when learning how to run a business (Fayolle, 2008). The European Commission (2013) has recognised entrepreneurship education as a tool to develop competences that are applicable in all life stages, with or without a commercial objective. It includes 
learning, education and training that promote an entrepreneurial spirit. The aim is to support the efforts of entrepreneurs so they can achieve societal sustainable values, as all entrepreneurs of the future are in school today (Lindner, 2018).

Lindner (2018) pointed out that the world would be very different if there had not been active and innovative pioneers who had boldly introduced new ideas. Many of these pioneers have also encountered opposition to their new ways of thinking. Others have hoped too that they would imitate traditional patterns of thinking. However, active and innovative people are a prerequisite for future development. Europe needs innovative entrepreneurs and a flexible work force with key life competences (European Commission, 2013).

Unfortunately, children's economic education is still characterised by guiding pupils to imitate current patterns of economic activities, and to adopt them as such (Ruckenstein, 2013, p. 164). Moreover, the Nordic Council of Ministers (2010) emphasised that as a teacher should use himself/herself as a role model when teaching children under the age of 10 .

Ruckenstein (2013) noted that, if consumer education encouraged dialogue between children and adults, children and adolescents might have the ability to question the prevailing economic thinking and exchange relationships. This could enable children to actually present new perspectives on the economy to adults. The Nordic Council of Ministers (2010, p. 9) suggested that "consumer education today should provide citizens with the tools and skills to have an influence. It should be re-evaluated in the light of contemporary challenges".

The topical concern, such as plastics and plastic waste, provide broad didactical and methodological potential for the education for sustainable development (Kerscher, 2019). The OECD (2009) emphasised that policy makers need stakeholders' assistance, including help from teachers, to identify consumer education needs. Teachers play a central role, since they interact with learners every day. However, there is a large research gap in terms of studies investigating teachers' perceptions of children's consumer education, especially at the primary school level.

Taking advantage of the opportunity to provide consumer education at schools requires teachers to be familiar with consumer issues (OECD, 2009). As educators at a faculty of education in Ontario, Canada, Asworth and Steele (2016) noticed that teacher candidates (TCs) usually purchase new materials whenever they have an assignment requiring students to create objects. Even though the TCs were encouraged to keep the things they had made for use as classroom samples, many decided to throw them away soon after the project had ended. Asworth and Steele (2016) were concerned about this unsustainable consumer behaviour, so they wanted to challenge TCs to use recycled and/or natural materials in their construction projects. By fulfilling this requirement, the TCs saved money, practiced sustainability and learned to think more creatively (Asworth \& Steele, 2016).

To support teachers' consumer educational skills, it is important to study their perceptions of these themes. Thus, the present study aimed to investigate the perceptions and experiences of primary school teachers in Finland regarding children's consumer education in schools.

This article is structured as follows. First, an overview of consumer education in the school context is provided, followed by a description of the research design. Then, 
the research findings are presented, and, based on these findings, implications for practice and further research are presented.

\section{Overview of Consumer Education}

The paradigm shift away from the conventional approach of consumer education can be seen in the work of researchers who have drawn on the principles of citizenship and sustainability (McGregor, 2008). Conceptually, the focus of the conversation about worldwide consumer education has moved away from the narrow issues of household consumption and market functioning towards a broader global view (Goldsmith \& Goldsmith, 2011; Goldsmith \& Piscopo, 2014). Sustainability not only refers to the environmental impact of consumption, it also encompasses economic and social sustainability (McGregor, 2008; Goldsmith \& Piscopo, 2014). McGregor (2008) pointed out that consumer educators need to be aware of the ideologies and paradigms that shape their work.

The Nordic Council of Ministers (2010) has suggested that the following skills are required:

- Creativity and innovation,

- Problem-solving skills and critical thinking,

- Communication and media skills,

- Information management skills,

- Civic skills, to which the concepts of consumer behaviour and consumer citizenship are closely linked,

- Social skills and attitudes,

- International skills (i.e. language skills and awareness of other cultures).

With these skills in mind, the Nordic Council of Ministers (2010) has suggested that the objective of consumer education be based on two integrative themes: sustainable consumption and media and technology literacy. Furthermore, these key themes are included in four fields of consumer education: management and participation at home, consumer rights and responsibilities, personal finances and marketing and commercial media.

The set learning objectives can be achieved when the entire arena in which consumer habits are formed (Figure 1) is considered (Nordic Council of Ministers, 2010.) Phelan, Davidson, and Cao (1991) presented a model of the interrelationships between the worlds of the students' family, their peers and their school, and how the meanings and understandings of these worlds affect the students' commitment to school and learning. Many studies have shown the effectiveness of using social influence to promote sustainable behaviour: the individual receives knowledge and is motivated to form new attitudes and behaviours (Goldsmith \& Goldsmith, 2011). Moreover, the multiple worlds model focuses on the students' perceptions of the boundaries between the worlds and the adaptation strategies they use to move from one context to another (Phelan et al., 1991).

This multiple worlds model provides teachers with a way to have a more holistic view of their students (Phelan et al., 1991). The children move, daily, from one context to another. To make consumer education in school relevant for learners, children should feel safe to deal with the contradictions of these contexts. It is crucial that children not feel the need to hide the important features of their lives (Phelan et al., 1991). 
Teachers need to be equipped with the relevant competences because they play a central role in children's consumer education. However, there has been a significant change in emphasis from the more prescriptive approaches to supporting, informing and mobilising teachers (Brennan, Vlaev, Blakemore, \& Smith, 2017). An entrepreneurial and innovative spirit is needed; thus, teachers do not provide students with the answers, rather, they help them research and identify the right questions and find the best answers (European Commission, 2013).

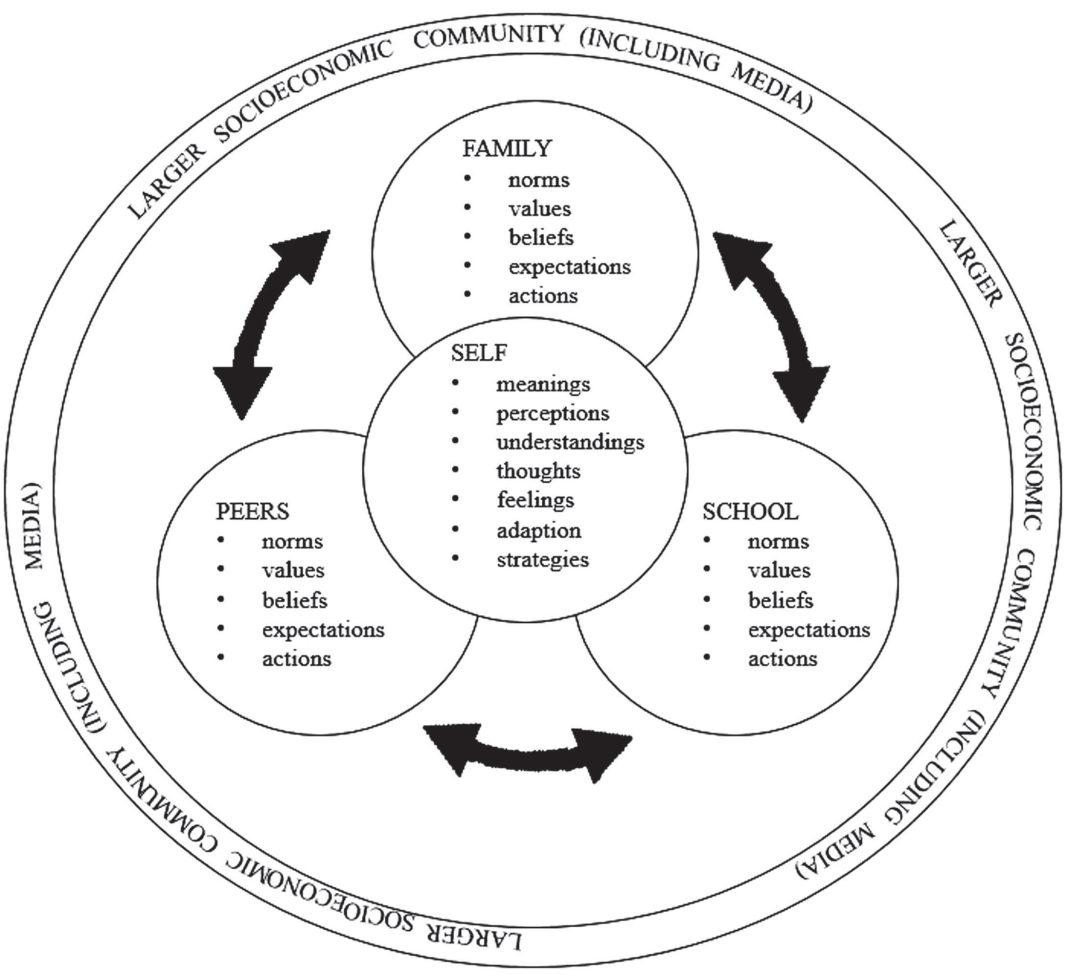

Figure 1. The multiple worlds model (Phelan et al., 1991; modified by the Nordic Council of Ministers, 2010)

Teachers' perception of children's consumer education, especially at the primary school level, is a relatively under-researched topic. That is why the present study used a phenomenographical research approach. Phenomenography aims to describe, analyse and understand the various ways in which a group of people experience and perceive the same phenomenon, and how that understanding forms a basis for their actions (Barnard, McCosker, \& Gerber, 1999; Marton, 1981, 1986).

A distinction should be made between two perspectives. Phenomenography aims to describe people's experience of various aspects of the world (second-order perspective), and the first-order perspective aims to describe the world as it is (Marton, 1981; Barnard et al., 1999). The second-order perspective emphasises that reality is constructed socially and constructively (Huusko \& Paloniemi, 2006). People's perceptions and thoughts are a valuable subject for research. 
The goal is to identify and systemise these different perceptions. Even one single conception is meaningful because the aim is to obtain a set of categories that describes the different ways the participants have understood and experienced the studied phenomenon (Dasborough, Lamp, \& Suseno, 2015). This organised set of categories of descriptions is called the "outcome space" of the phenomenon being studied. However, phenomenography also focuses on looking at the underlying meanings of these conceptions and outcome spaces, the relationships between them and their implications in a specific context (Walsh, Howard, \& Bowe, 2007.)

\section{Data Collection}

Conducting interviews is a flexible way to collect data because it enables multisensory interactions between the interviewer and the interviewee (Cohen, Manion, \& Morrison, 2011). Huusko and Paloniemi (2006) stated that, in phenomenography, openended questions are central to the collection of data in order to allow different perceptions to emerge. Using interviews as a data collection method enables personalisation and the ability to include additional questions to gain a greater depth of information (Cohen et al., 2011).

Concepts related to consumer education are not yet well-established in the Finnish language. Therefore, semi-structured interviews were used in this study. Semi-structured interviews reflect research questions, but they still enable the collection of in-depth data since the interviewer can ask questions that were not foreseen when the research questions were determined (Newby, 2010, pp. 340-342). The themes of the questions were prepared, but the interviewer was not restricted to strictly following the planned structure. The interviews were dialogue-based, so there was a chance to digress from the planned questions. This allowed the participants to express the various ways they perceive the phenomenon.

The empirical data of this research consists of six individual interviews (T1-T6) conducted in Finland. The respondents were one male teacher and five female teachers; their students ranged in age from 7 to 13 . The interviews lasted 45 minutes, on average, and they were transcribed verbatim from the recordings. Participation was voluntary, and confidentiality was assured. The interviews were conducted in Finnish, and the quotes presented in the study's results discussed in this paper have been translated into English.

\section{Method of Analysis}

Phenomenographic analysis is undertaken through an exploration of data obtained from a group of participants (Barnard et al., 1999). The approach is data-driven, so previous studies and theories do not predetermine categorisation of the data. The collected data are the basis for the categorisation (Marton, 1986). However, this does not mean that it would be unnecessary for a researcher to explore previous studies related to the phenomenon. Theoretical knowledge helps the researcher think critically. It would certainly be valuable to be aware of previous scientific discussion.

The aim is to qualitatively identify the various ways that participants describe and express their perceptions of the phenomenon studied (Barnard et al., 1999). Transcripts of the teachers' interviews were read and reread carefully, looking for significant state- 
ments. After these significant statements were found, the researcher simplified them. This was done because the research focuses on the meanings of the teachers' perceptions, not on the content of the participants' exact quotes.

The next step of the data analysis was to look for the similarities and differences among the responses, and group them accordingly. Dasborough et al., (2015) stated that phenomenographic analysis is an ongoing interpretative and iterative process. During this process, the formed categories change and develop as a result of the researcher's interpretation of the data. According to Marton (1986), this testing, adjusting, retesting and again adjusting phase is characteristic of the phenomenographic analysis.

Marton (1986) pointed out that each category is a potential part of a larger structure in which the category is related to other formed categories of descriptions. The researcher explores the potential interconnections between the categories. The aim is to find the structural framework in which various categories of understanding exist (Marton, 1986). Ultimately, the outcome space of this study was developed and tested against all the interview transcripts.

\section{Research Findings}

The analysis of the interview transcripts revealed a set of categories that describes the interview participants' perceptions of children's consumer education in a primary school context. These categories are:

- Themes,

- Actors, their roles and the context in consumer education,

- Teaching methods,

- Challenges,

- Expectations of consumer education resources.

Themes. This research reveals the themes that teachers relate to the content of consumer education. These are presented in Figure 2.

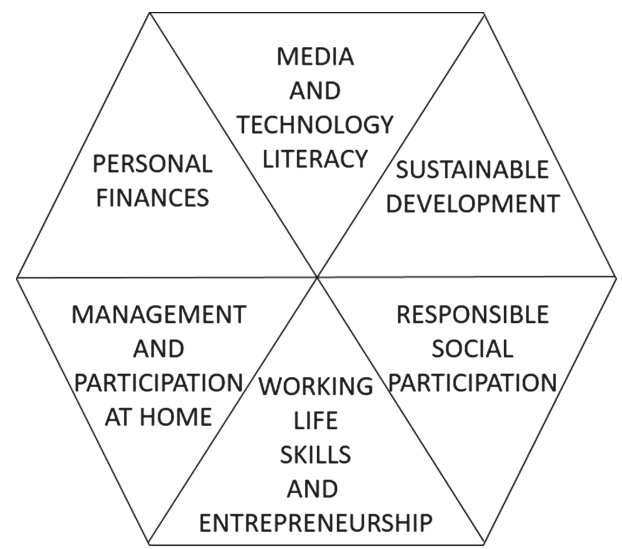

Figure 2. The themes teachers relate to consumer education

In every interview, the teachers talked about sustainable development. Since the subject of social studies starts in the $4^{\text {th }}$ grade in Finland, the $1^{\text {st }}$ and $2^{\text {nd }}$ grade teachers, especially, felt that consumer education focuses mainly on sustainable development. 
Specifically, environmental sustainability was discussed. Less attention was given to social and economic sustainability, but those were still mentioned. Cultural sustainability was not mentioned in the participants" answers. As T4 noted, "We have discussed with the kids where are the goods imported from... Is it possible that child labour has been used? How the goods were produced?" Understandably, the Nordic Council of Ministers (2010) suggested that, in the future, educational programmes should pay more attention to the way that sustainable development and consumption cover all four aspects of sustainability, not just the ecological area.

The teachers also related the theme of media and technology literacy to consumer education. The skills needed to recognise and interpret marketing and commercial media were repeated in their answers: T6 noted: "First the kids didn't even consider them as commercials". Behaviour in social media and criticism in the use of digital media were mentioned as well. However, one of the interviewees talked about a project with the university related to social entrepreneurship. During that project, the pupils practiced their communicating with one another to determine what kind of impression they wanted to give and how to market themselves.

Personal finances were also one of the fields the teachers related to consumer education. The aim is to help children develop their understanding of concepts, such as the value of money and the relationship between the price of goods, and the money available to them. Teachers of $4^{\text {th }}-6^{\text {th }}$ grade students noted that the subject of social studies has brought new perspectives to classroom discussions. For example, students discuss how to recognise the factors that influence financial decision-making. One of the participants said that the concepts related to currencies and exchange rates had become more concrete for children because they take a field trip abroad.

The teachers also brought up the topic of management and participation at home. The aim is to, for example, enhance children's ability to take care of their belongings and draw attention to the use of common resources as a member of the family and the school community. The teachers also mentioned that daily skills are included in the Finnish curricula as a cross-curricular theme. Teachers of $4^{\text {th }}-6^{\text {th }}$ grade students said that they had discussed these concepts in the classroom, for example, how the household works, household-related factors and domestic activities.

The interviews revealed that the teachers also relate the consumer educational contents to a context that is larger than just the personal and household level. Responsible social participation emerged from the data. The aim is to enhance pupils' awareness about how they can influence their own community and, more broadly, how society works and how they can contribute to its development. Teachers have discussed with the children what issues they are personally interested in promoting. For example, the youth climate strike on 15 March 2019 had increased debate about this issue in the classrooms. However, it was pointed out that society, as a concept, is very complex and challenging to explain to a child so he/she can truly understand it.

The teachers also related working life skills and entrepreneurship to consumer education. One of the participants said that she has regular cooperation with the pupils' parents and their employers. That teacher arranged visits outside the school to familiarise students with different professions. Other participants also mentioned visits outside the school, but, in these cases, cooperation was less common.

It was pointed out that some of the pupils have no idea how much money a working adult earns. One teacher said that once the pupil had brought that up, she could not ask 
her parents about their salary. It is not appropriate in all families to talk about salary issues, so this teacher considered it important to discuss the salaries of different professions in the classroom.

One of the participants related social entrepreneurship to consumer education. This teacher said that she had participated with her pupils in a collaboration project with the university. They had implemented a learning package that included 12 lessons related to social entrepreneurship. The teacher noted that the pupils had applied concepts from the business world, such as slogans and logos, to themselves. This gave them a more specific understanding of these concepts.

Actors, their roles and the context in consumer education. In all the interviews, consumer education was viewed as a task for both the school and the family. However, the teachers' perceptions of how responsibilities should be shared between the actors varied. Some felt that families have the main responsibility for their children's consumer education, because families have different kind of values that influence their purchasing decisions. The participants noted that parents' consumption habits have an impact on their children's consumer skills. A weekly allowance was considered to be a good way for students to practise handling money, but, still, it was a family decision. One of the teachers said that she talks more about financial issues at home with her own children than she does at school with her pupils. The teachers also noted that a child can experience entrepreneurship differently if there are entrepreneurs in his/her family.

One of the interviewees felt that discussions about money are families' private matters, so she was careful when discussing consumption and money in the classroom. This teacher stated that she could discuss monetary issues superficially, but she did not feel it was natural to have deeper discussions related to money. However, she mentioned that she remembered a conversation between pupils that had a very comparative tone in regard to purchases that had been made, and that, as a teacher, she felt the need to intervene, noting that each family has its own habits.

The teachers' discussions with families related to consumption and money were infrequently raised in the interviews. Only a few comments emerged:

"These kinds of discussions with the parents have focused on practical matters, such as raising money for a field trip. I don't remember that we have had any other discussions related to this." (T5)

"I've felt a strong change in my own thinking. I haven't really been a green person before. The media has affected and the ecological attitudes of my pupils' families. For example, one dad sent me a message and suggested a greener option for a plastic bag that I had asked children to bring with them". (T2)

In many of the interviews, the participants pointed out how important it is that consumer education be targeted to a specific age group, based on the children's experiences. It is important to discuss the conflicts children experience in their daily life in the classroom. For example, the children had noticed some differences in the recycling systems between their homes and school. One of the interviewees mentioned that her pupils had been very eager to mention their own criteria for purchasing a new phone. The teacher felt that the students had a good conversation when they compared their purchase criteria.

It was also noticed that the children's discussions reveal how their friends are influencing their purchasing decisions. A child may try to obtain a certain status based 
on his/her belongings. The pupils' conversations must be listened to carefully so that friends are not judged by the clothes they wear, for example.

Some of the participants suggested that, specifically, the school should be responsible for the children's consumer education. It was argued that not all of the family's money and consumer issues are discussed, so it is important that a child be given the opportunity to enhance his/her consumer skills at school. The teachers' comments referred to the curriculum objectives, so it is crucial how these themes are included in the curriculum. Textbook authors were also seen as stakeholders. Moreover, the teachers mentioned collaboration with organisations, local companies and municipal stakeholders, universities and international projects.

However, more than the role of the school, teachers talked about the role of the teacher in consumer education. In many of the interviews, it was noted that the implementation of consumer education in schools varies widely, depending on, for example, the teachers' personal interest in consumer education themes and their conception of their skills in consumer education. It was also mentioned that media influences the perceptions of pupils and teachers. One of the participants mentioned that, since the primary school system in Finland is free, it affects to the way financial issues and entrepreneurship are being discussed.

Teaching methods. The findings provide information about the methods elementary school teachers use in consumer education. Classroom discussions and different readymade materials were mentioned most frequently. The teachers who taught social studies said that they had used textbooks and online materials. In contrast, the $1^{\text {st }}$ and $2^{\text {nd }}$ grade teachers felt that there is a lack of ready-made materials dealing with money and consumption that are suitable for younger children. However, these teachers said that themes related to sustainable development and healthy choices were, to some extent, addressed in textbooks. Two of the participants mentioned that, for example, different organisations' websites and videos had been used as a basis for classroom discussions.

Illustrating classroom samples came up in the interviews, especially regarding the rational use of materials, recycling and advertising. The guidance for sustainable material consumption was not limited to younger children; $4^{\text {th }}-6^{\text {th }}$ grade teachers felt that there is always potential to reduce material waste. Recycled materials were often used in the arts. According to T3: “Usually we send a message to children's parents beforehand and ask if they have certain material available, for example, empty milk cartons. Nowadays we avoid buying everything as new from stores but prefer recycled materials".

Different kinds of events had also been organised. Flea markets were mentioned in many of the interviews. The children had, for example, made the ads and price lists and run a cafe or their own stand at these events.

Some of the consumer education themes can also be seen in the schools' daily life; for example, activities of the student body were mentioned. Related to a Finnish school feeding programme, one of the participants (T4) pointed out: “....all bio-waste is weighed at our school and the children get information about these amounts. The goal is to encourage children to minimise the food waste".

Recycling was also taken care of in various ways, for example textbooks were recycled at many of the schools. However, two of the participants felt that, even though recycling is part of the school's daily life, sustainable consumption is not otherwise discussed at the school level. T5 said: "There is very little discussion about consumption at 
the school level. Recycling is somehow visible, but we should have decent recycling boxes in the classrooms. Now there is a ragged box for paper recycling, that doesn't give the impression that recycling is somehow valuable action".

At some schools, pupils participate in making annual material orders with their teachers. One of the interviewees said that he had instructed his pupils to order textbooks for themselves for the following year. The teacher felt that this would give the children a clear idea of the value of the books they have. Another participant said that she and her pupils had collaborated to consider what equipment they would need for the next year, e.g. for the outdoor games. In these two interviews, both of the teachers also pointed out that all the school purchases are made for actual needs; nothing is bought for storage, unused, or only for the joy of purchasing it.

T1 said: "We made annual orders together with the children. I told the kids our budget, and we discussed what we really need. We calculated that, for example, two footballs cost 70 euros, and we considered what else we would get with the same sum. The kids didn't start to wonder why we didn't order 10 footballs, because they realised the school had given us a certain budget".

One of the interviewees had implemented a play shop in his classroom. Three other participants said that they had not yet implemented a play shop in their classroom, but they had plans to try it. Two of the teachers hoped that they would get more ideas, especially for games and activities.

The teachers had made visits outside the school, for example to enterprises, landfills and recycling centres, with the children. Visitors had also been invited to the school. However, different kinds of visits were rarely implemented. Most of the visits had been agreed upon, one-by-one, and there was no regular cooperation between the visitors. As previously mentioned, only one of the teachers had regularly collaborated with the parents and their workplaces concerning visits outside the school. Another participant had noticed that, at their school, the $7^{\text {th }}-9^{\text {th }}$ grade teachers regularly collaborated with nearby entrepreneurs, but this was not the case for $1^{\text {st }-} 6^{\text {th }}$ grade teachers.

The interviews revealed that the teachers are interested in welcoming visitors to their classes to discuss topics related to the consumer education themes. However, according to these interviews, it is more common that the pupils visit places outside the school. Ruskovaara and Pihkala (2013) also reported this in their study about entrepreneurship educational practices. They considered that this could possibly be due to the fact that teachers want to expand the learning environment outside the school.

Functional teaching methods had been used, to some extent, in the classrooms. T2 said: "At the time of the parliamentary elections, we had our own elections in our classroom and voted for the top team of the class. We built a voting booth and used ballots". T4 said: "We made a Christmas calendar of recycled goods. Each of the kids brought one unnecessary item from home".

Some of the interviewees also said that they had participated in the Yrityskylä simulation with their pupils. The Yrityskylä learning environment for $6^{\text {th }}$ graders is a children's miniature city where pupils work in a profession, earn money and act as consumers and citizens. The Yrityskylä for $6^{\text {th }}$ graders consists of teacher training, 10 lessons and a visit to the learning environment. It reaches $75 \%$ of the $6^{\text {th }}$ graders in Finland (TAT Yrityskylä, 2019). A common response from the teachers was that the Yrityskylä visit had made a strong impression on the children, who found it very meaningful. The teachers also felt that the visit had been easy to implement. 
The teachers mentioned different kinds of project works and participation in campaigns. The children had, for example, donated their unnecessary toys. One of the interviewees felt that she had to clarify, for herself, the themes and contents of consumer education so that she could try to apply the phenomenon-based learning method with her pupils.

Although many teaching methods were described in the interviews, classroom discussions and ready-made materials were still mentioned most frequently. Many participants pointed out that the consumer educational contents are addressed in a very superficial way. Moreover, the responses repeated the conditional form. T1 said: "I could call and ask for an expert to visit our school, but I have no idea where to call". The interviews revealed the teachers' perceptions of the challenges of consumer education, as well as their expectations of resources and support. These findings are presented in the next section.

Challenges. The data analysis also revealed some of the challenges that the teachers noted concerning consumer education in primary schools. Curriculum overload was mentioned. There is already a large range of learning objectives, so it is challenging to find enough time to include everything. Moreover, the weak availability of ready-made materials for younger children was mentioned. The $1^{\text {st }}$ and $2^{\text {nd }}$ grade teachers noted that it is not easy to find ready-made materials about consumer education for their students. The topics focus mostly on recycling. Some of the interviewees pointed out that while it is possible to find appropriate material on the Internet, doing so takes time and effort. In Finland, the subject of social studies starts in the $4^{\text {th }}$ grade, so $4^{\text {th }}-6^{\text {th }}$ grade teachers said that the availability of ready-made materials was good, especially online materials. However, some of the teachers felt that consumer education topics were more superficially addressed in the materials. Delving deeper into the topic takes more time and effort. T2 said: "I haven't seen any ready-made guide that would be directed to primary schools".

In several of the interviews, the teachers thought that consumer education practices vary widely, depending on the teacher's personal interests in consumer education themes and his/her willingness to make an effort. T6 said: "I believe that, for many teachers, this is quite an unfamiliar topic. If the teacher in his/her daily life favours responsible consumption, it also reflects in the teaching. But if the teacher hasn't thought about these things, the teaching can remain superficial".

It is also challenging to set common goals in the school community and to engage people, so that the teacher does not feel alone. Two of the interviewees said that they do not feel encouraged to teach consumer education. There were difficulties in networking with other stakeholders, as well.

The interviewees also pointed out the lack of teacher training. Some of the participants felt insecure about the objectives concerning consumer and entrepreneurship education. For example, one of the teachers said that she did not know the aims of entrepreneurship education, and that she would not recommend running a business to her own children because she feels that it is an uncertain source of income. There were also difficulties in recognising all the content related to these themes. More training was desired, so that consumer education would be more child-oriented.

The wealth inequalities of the families were also considered to be a challenge. One of the interviewees felt that discussions about money are families' private matters, so she was careful when discussing consumption and money in the classroom. 
Due to budget constraints, the school may not have access to chargeable materials. The budget also limits the number of the staff. One of the teachers pointed out that her collaboration with the university has enabled pupils to participate in several projects. For example, the presence of TCs is a significant help with project implementation.

Expectations of consumer education resources. The analysis of the interview transcripts revealed that teachers have requirements and expectations concerning consumer education resources and materials. The materials were expected to be free, easy-to-use, up-to-date and available in various formats. Teachers mentioned the need for versatile online materials, a clear textbook focusing on consumer education themes and printable materials. T4 said: "Searching for material is always a problem. It doesn't have to be a book publisher's material, as long as it's easily available”.

The participants expected that the children's age and daily life experiences would be addressed in the ready-made materials. Adaptable and editable materials were needed, not strict guidelines. Practical ideas and tips were needed to support teaching. Tips for games and activities were also welcomed. The $1^{\text {st }}$ and $2^{\text {nd }}$ grade teachers felt that that there is no consumer education material targeted at teachers. They requested some kind of information package for teachers, for example, to support the classroom discussion. There was also a need for an interactive platform where teachers could share their experiences and ideas.

\section{Discussion}

This paper aimed to discuss the perceptions and experiences of primary school teachers in Finland regarding children's consumer education in schools. Figure 3 illustrates these perceptions.

The results of this study reveal that teachers relate the following themes to consumer education: sustainable development, media and technology literacy, personal finances, management and participation at home, responsible social participation and working life skills and entrepreneurship. The findings are very similar to the consumer educational themes and fields suggested by the Nordic Council of Ministers (2010). In the present study, consumer rights did not emerge from the data. Furthermore, it was interesting to note that the teachers in this study related social entrepreneurship and working life skills to consumer education. These two issues are not clearly addressed in the Nordic Council of Ministers' strategy.

Regarding the environment in which consumer skills are acquired, this study's findings reveal that, in Finland, teachers feel that they have a significant impact on what kind of consumer education children receive in school. However, the participants noted that implementations vary greatly depending on, for example, the teachers' personal interests in the issues and their willingness to make an effort and trust in their own competence as a consumer educator.

Furthermore, while recognising that both families and teachers have an influence on how children's consumption patterns are formed and developed, it is surprising that this study found that there is hardly any discussion between teachers and families about consumption and money. Stakeholders, including teachers and parents' associations, should work together to provide meaningful, relevant and inspiring consumer education for children. 


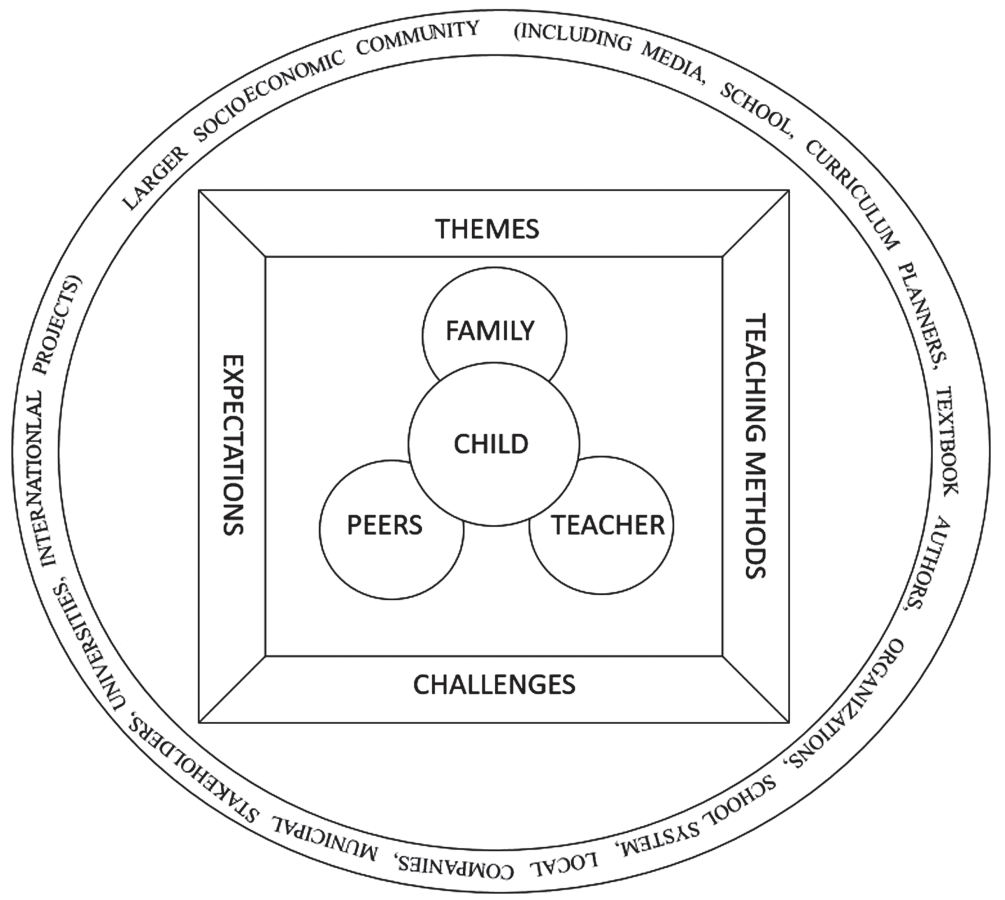

Figure 3. Teachers' perceptions of children's consumer education in primary schools in Finland (modified from the multiple worlds model)

Although many teaching methods were mentioned in the interviews, classroom discussions and ready-made materials were most often addressed. It is interesting that these traditional practices were also popular in entrepreneurship education in basic and upper secondary school education (Ruskovaara \& Pihkala, 2013). Conditional form was repeated in the teachers' expressions: if there was time, money, support, teacher training, etc.

The challenges of consumer education found in this study are very similar to those in the OECD Report, which is based on surveys conducted in 27 countries, including four non-OECD countries. According to the OECD Report, to provide consumer education in schools many challenges must be overcome, including curriculum overload, difficulties in motivating teachers, lack of teacher training, difficulties reaching out effectively to regional and local communities, improving co-operation and co-ordination among stakeholders, budget constraints and the dynamic nature of the markets; thus, teachers need to update their knowledge constantly (Ueno, Olczak, \& Takahashi, 2009, p. 184). In the present study, the wealth inequalities of the families were also mentioned as a challenge for teacher. The teachers noted that it was important to deal with these issues in the classroom with sensitivity.

The teachers also mentioned their expectations and the requirements of consumer education resources. Nunn and Cochrane (2012) also reported on the characteristics that teachers desire in consumer education resources. Although they focused on teachers of 12-18-year-old students, the findings are similar to the results reported in this paper. According to Nunn and Cochrane (2012), the desired features of consumer education 
resources requested by teachers include: linked to their subjects; easy and free to use; reliable and authoritative; accurate and up-to-date; adaptable and editable; available in multiple formats; relevant to day-to-day life; tailored to different age groups, practical and attractive, contain expert input; interactive and multimedia; and facilitate sharing. As Goldsmith and Piscopo (2014) pointed out, there is a need for dynamic resources that inspire teachers so they can motivate their pupils to be more constructivist in their learning.

OECD (2009) has noted that including consumer issues in teacher training programmes could ensure that teachers are sufficiently well-versed about consumer issues, thereby providing them with effective teaching techniques. However, it is worth considering the extent to which consumer issues can be included in education programmes.

\section{Conclusion}

There are many topics that different parties expect to be added to and/or strengthened in teacher education. Instead, there is great potential to improve co-operation and coordination among stakeholders at local, national and international level. For example, different regions have their own characteristics, and utilising these in strategic networking can create synergies for the stakeholders in the area. Furthermore, creative forms of consumption may be developed in more innovative learning environments.

Transition towards a circular economy requires pioneers who see value in a new way and are ready to boldly promote sustainable economic thinking. As mentioned before, children and adolescents might have the ability to question the prevailing exchange relationships. When considering the approriate approaches for consumer education, it should be noted that children may present new perspectives on the economy to adults.

Further research is needed to identify effective ways to develop active networks among relevant stakeholders. The findings of the present study are worth exploring when considering how to support teachers' consumer educational competences for a sustainable future.

\section{References}

Asworth, E., \& Steele, A. (2016). “I'm just going to buy that!": Confronting consumerism in teacher education. Discourse and Communication for Sustainable Education, $7(1), 37-48$.

Barnard, A., McCosker, H., \& Gerber, R. (1999). Phenomenography: A qualitative research approach for exploring understanding in health care. Qualitative Health Research, 9(2), 212-226. doi:10.1177/104973299129121794

Brennan, C., Vlaev, I., Blakemore, M., \& Smith, N. (2017). Consumer education and empowerment in Europe: Recent developments in policy and practice. International Journal of Consumer Studies, 41(2), 147-157.

Cohen, L., Manion, L., \& Morrison, K. (2011). Research methods in education $\left(7^{\text {th }}\right.$ ed.). London: Routledge. Retrieved from http://search.ebscohost.com.pc124152. oulu.fi:8080/login.aspx?direct=true $\& \mathrm{db}=$ nlebk\&AN=548475\&site=ehost-live

Dasborough, M., Lamb, P., \& Suseno, Y. (2015). Understanding emotions in higher education change management. Journal of Organizational Change Management, 28(4), 579-590. 
European Commission. (2013). Entrepreneurship education: A guide for educators. Brussels. Retrieved from https://bethechange-project.eu/wp-content/uploads/2017/ 09/Entrepreneurship-education-Guide.pdf

Fayolle, A. (2008). Entrepreneurship education at a crossroads: Towards a more mature teaching field. Journal of Enterprising Culture, 16(4), 325-37.

Goldsmith, E. B., \& Goldsmith, R. E. (2011). Social influence and sustainability in households. International Journal of Consumer Studies, 35(2), 117-121.

Goldsmith, E. B., \& Piscopo, S. (2014). Advances in consumer education: European initiatives. International Journal of Consumer Studies, 38(1), 52-61.

Huusko, M., \& Paloniemi, S. (2006). Fenomenografia laadullisena tutkimussuuntauksena kasvatustieteissä [Phenomenography as a qualitative research method in education]. Kasvatus [Education], 37(2), 162-173.

Kerscher, U. (2019). Towards a sustainable future? The EU policies concerning plastics and their didactical potential for primary and secondary teaching. Discourse and Communication for Sustainable Education, 10(1), 47-62.

Lindner, J. (2018). Entrepreneurship education for a sustainable future. Discourse and Communication for Sustainable Education, 9(1), 115-127.

Low, M. B. (2001). The adolescence of entrepreneurship research: Specification of purpose. Entrepreneurship Theory and Practice, 25(4), 17-26.

Marton, F. (1981). Phenomenography: Describing understandings of the world around us. Instructional Science, 10, 177-200.

Marton, F. (1986). Phenomenography: A research approach investigating different understandings of reality. Journal of Thought, 21(2), 28-49.

McGregor, S. L. (2008). Ideological maps of consumer education. International Journal of Consumer Studies, 32(5), 545-552.

McNeal, J. U. (2007). On becoming a consumer. The development of consumer behavior patterns in childhood. Amsterdam: Elsevier Inc.

Newby, P. (2010). Research methods for education. Harlow, England; N.Y.: Pearson Education Limited.

Nordic Council of Ministers. (2010). Teaching consumer competences: A strategy for consumer education. Proposals of objectives and content of consumer education, Nordic Council of Ministers, Copenhagen. Retrieved from https://www.kkv.fi/ globalassets/kkv-suomi/opettajalle/julkaisut/en/temanord-2010568_with-theappendix_final.pdf

Nunn, R., \& Cochrane, B. (2012). Consumer classroom. Presentation to the European Consumer Consultative Group on 29 November, 2012. Retrieved from http://ec. europa.eu/consumers/empowerment/minutes/pres08bis_minutes_2930112012_ en.pdf

OECD (2009). Consumer education: Policy recommendations of the OECD'S Committee on Consumer Policy. Retrieved from http://www.oecd.org/sti/ieconomy/44110 333.pdf

Phelan, P., Davidson, A. L., \& Cao, H. T. (1991). Students' multiple worlds: Negotiating the boundaries of family, peer, and school cultures. Anthropology \& Education Quarterly, 22(3), 224-250.

Rajala, A., Hilppö, J., Stenberg, K., Suvanto, T.-E., \& Mäki, L. (2015). Opetuksen omakohtaistaminen ja osallistava pedagogiikka [Personalization of teaching and participatory pedagogy]. In Cantell, H. (Ed.), Näin rakennat monialaisia oppimisko- 
konaisuuksia [How to build multidisciplinary learning entities] (pp. 97-106). Juva: Bookwell Oy.

Roland-Lévy, C. (2010). Children and money. In Marshall, D. (Ed.), Understanding children as consumers (pp. 149-164). Los Angeles: SAGE.

Ruckenstein, M. (2013). Lapsuus ja talous [Childhood and economy]. Helsinki: Gaudeamus.

Ruskovaara, E., \& Pihkala, T. (2013). Teachers implementing entrepreneurship education: Classroom practices. Education + Training, 55(2), 204-216.

TAT Yrityskylä. (2019). Briefly about TAT. Retrieved from http://www.tat.fi

Ueno, Y., Olczak, M., \& Takahashi, Y. (2009). Promoting consumer education: Trends, policies and good practices. Paris: OECD.

Walsh, L. N., Howard, R. G., \& Bowe, B. (2007). Phenomenographic study of students' problem solving approaches in physics. Physical Review Special Topics - Physics Education Research, 3(2), 020108. doi:10.1103/PhysRevSTPER.3.020108

Wilska, T.-A. (2008). Lasten materialistiset kulutusasenteet ja kuluttajaksi sosiaalistuminen [Children's materialistic consumption attitudes and socialization as consumers]. In Raijas, A., \& Wilska, T.-A. (Eds.), Perhe kulutusyhteiskunnassa [Family in a consumer society] (pp. 33-50). Helsinki: Kuluttajatutkimuskeskus.

Correspondence relating to this paper should be addressed to Kati Pajari, MSc. (Econ. \& BA), BA, and Sari Harmoinen, PhD, MSc, Education Dean, Faculty of Educational Sciences and Teacher Education, University of Oulu. Emails: kati.pajari@student.oulu.fi and sari.harmoinen@oulu.fi 